\title{
Re-criar a (na) Renda de Bilro: Analisando a Nova Trama Tecida
}

\author{
Andréa Vieira Zanella ${ }^{12}$ \\ Gabriela Balbinot \\ Renata Susan Pereira \\ Universidade Federal de Santa Catarina
}

\begin{abstract}
Resumo
Arte e criatividade são temas que têm suscitado o interesse de muitos pesquisadores de diferentes orientações teóricometodológicas e áreas do conhecimento. Visando a contribuir com o debate, é objetivo deste trabalho analisar o processo de criação/inovação em uma atividade específica, o fazer renda de bilro. As análises aqui apresentadas versam sobre o movimento de inserção de um sujeito na atividade rendeira na Ilha de Santa Catarina e foram tecidas a partir de suas próprias palavras. À luz dos aportes teóricos da Psicologia Histórico-Cultural, aspectos que singularizam tal sujeito constituíram-se como foco de análise, em especial aqueles relacionados ao movimento de criar nessa atividade.
\end{abstract}

Palavras-chave: Constituição do sujeito; criatividade; psicologia histórico-cultural.

Re-creating in (the) Bilro Lace: Analising the New Weft Woven

\section{Abstract}

Art and creativity are subjects that have risen the interest of many researchers from different theoretical and methodological approaches, as well as branches of knowledge ment. Aiming to contribute to this debate, the goal of this paper is to analyze the process of creation/innovation in a specific activity: weaving the Bilro lace. The analysis here presented points out to the insertion movement of a subject in the weaving activity at the Santa Catarina Island. This was possible to be made through the words of the researched individual. By studying the theoretical principles of the Sociocultural Psychology, some aspects that make the subject unique were the focused on the analysis, specially those related to the creative movement in the activity. Keywords: Constitution of the subject; creativity; sociocultural psychology.

Arte e criatividade são temas que têm suscitado o interesse de muitos pesquisadores de diferentes orientações teórico-metodológicas e áreas do conhecimento. Visando a contribuir com o debate, é objetivo deste trabalho analisar o processo de criação/inovação em uma atividade específica, o fazer renda de bilro.

As análises aqui apresentadas versam sobre o movimento de inserção de um sujeito na atividade rendeira na Ilha de Santa Catarina e foram tecidas a partir de suas próprias palavras. À luz dos aportes teóricos da Psicologia Histórico-Cultural, mais especificamente as contribuições de L. S. Vygotsky e alguns de seus interlocutores atuais, aspectos que singularizam tal sujeito constituíram-se como foco de análise, em especial aqueles relacionados ao movimento de criar nessa atividade.

\section{Considerações Iniciais}

Dentre os significados do verbo criar que constam nos dicionários de língua portuguesa destacam-se: “1. Dar

Endereço para correspondência: UFSC/CFH/Departamento de Psicologia, Campus Trindade, 88010-970, Florianópolis, SC. Fone/Fax (48) 3319984.E-mail: azanella@cfh.ufsc.br

As autoras agradecem ao CNPq pelo apoio recebido. existência a; tirar do nada (...). 2. Dar origem a; gerar, formar (...). 3. Dar princípio a; produzir, inventar, imaginar, suscitar (....)." ( Ferreira, 1997, p. 498) O que caracteriza essas definições é o fato de conceberem o criar como sinônimo de produção de algo novo, fruto da imaginação de quem o produz e desvinculado do que já existe. Essa também é a visão que se encontra no senso comum: quando se fala em algo criativo, logo remete-se ao inusitado, surpreendente, o que na maioria das vezes está restrito a grandes artistas. A criatividade é, assim, desvinculada do cotidiano e atribuída a pessoas que supostamente se encontram muito distantes da maioria da população: os gênios.

Contrapondo-se a essa idéia, Wolff (1982) defende que não há utilidade em considerar o trabalho artístico como diferente de qualquer outro, pois a atividade criativa ou inovadora também se faz presente em outras áreas da vida do sujeito. Essa autora considera o trabalho como atividade humana básica e desde que esse não seja forçado, deformado ou alienado, constitui uma atividade criativa livre. Todos os trabalhos - incluindo-se a arte - são formas do ser humano se expressar e, assim, falam pelo ser humano e sobre ele. À afirmação de Wolff acrescemos 
que ambos, criatividade e trabalho, são, além de constituídos pelos sujeitos, constituintes destes.

A atividade criativa não se separa, então, de nenhuma outra atividade humana. Se a impressão contrária perpassa tanto os significados do dicionário quanto o senso comum, isto se deve ao fato de não a enxergarmos no trabalho, em virtude da forma fragmentada e alienad como este tem se apresentado no modo de produção capitalístico $^{2}$. Decorrente dessa cisão arte/trabalho produz-se outra - artista/trabalhador - que resulta em formas diferentes de se conceber o resultado de suas atividades.

Ao analisar os lugares sociais da arte e dos artistas no início deste século, mais especificamente os efeitos da reprodutibilidade técnica das obras de arte, Benjamin (1996) destaca que a lógica do mito do artista produz uma clara separação social na medida em que engrandece e eterniza tanto os criadores quanto as obras de arte. Produz-se assim o que Benjamin chama de aura: “... uma figura singular, composta de elementos espaciais e temporais: a aparição única de uma coisa distante, por mais perto que ela esteja." (p.170)

A lógica do criador também se apresenta na primeira definição do dicionário “ dar existência a; tirar do nada (...)". Considerando tal definição, cabe indagar que concepções de sujeito e sociedade pautam essa leitura. Certamente as que opõem sujeitos e suas respectivas produções, atribuindo a fatores de ordem biológica ou espiritual suas características e, consequentemente, isolando-os dos resultados das atividades que engendram. No que se refere à arte e à criatividade, essa idéia exalta a imagem do criador no momento em que esse conclui sua obra e, uma vez considerada a-historicamente, essa se assemelha a algo de ordem divina ou mágica desvinculada do contexto de sua produção.

Todavia, a pesquisa sobre a gênese da capacidade criadora, sua constituição e direção mostra, a partir da Psicologia Histórico-Cultural, que tal atividade não se encontra desconectada da vida cotidiana: ao contrário da definição trazida pelo dicionário, há uma relação intrínseca entre criação e realidade. "Seria um milagre que a imaginação pudesse criar algo do nada, ou que dipusesse de outra fonte de conhecimento distinta da experiência

2 "Guattari acrescenta o sufixo 'ístico' a 'capitalista' por lhe parecer necessárí criar um termo que possa designar não apenas as sociedades qualificadas como capitalistas, mas também setores do 'Terceiro Mundo' ou do capitalismo 'periférico', assim como as economias socialistas do países do leste, que vivem numa espécie de dependência contradependência do capitalismo. Tais sociedades, segundo Guattari, em nada se diferenciariam do ponto de vista do modo de produção da subjetividade" (Rolnik, 1986, citado por Guattari \& Rolnik, 1986, p.15). anterior (...) a fantasia constrói sempre com materiais tomados do mundo real." (Vygotsky, 1990, p. 16-17)

Segundo Vygotsky (1990), a atividade criadora está em relação direta com a riqueza e variedade da experiência humana, pois essa experiência constitui-se como o material com que o homem "ergue seus edifícios de fantasias." Nesse sentido, o sujeito que cria reorganiza diferentes elementos oriundos de sua experiência que, em princípio, não têm qualquer vínculo. A criatividade tem sua expressão máxima no processo de combinação diferenciada do que era conhecido até então, formando o novo, onde a imaginação se destaca.

À imaginação é dada grande importância pois, antes de iniciar uma atividade, o homem pode elaborá-la na forma de idéias. Isso lhe permite ver além do imediato e projetar-se para o futuro, possibilita pensar o processo de trabalho e antecipar seu resultado. Antes do produto da atividade adquirir forma material, há a sua idealização, a qual pode ser modificada no decorrer da própria atividade. Nesse sentido, em qualquer atividade realizada pelo homem, seja a produção de uma peça de renda de bilro, uma escultura ou uma mesa, a imaginação criadora se faz presente: “... a imaginação orienta o homem no proceso da atividade mediante a criação de um modelo psíquico de produtos final e intermediário do trabalho, o que contribui para a sua materialização objetiva." (Petrovski, 1979, p. 372)

Contudo, sabe-se que o pleno domínio do processo e do resultado das atividades humanas é uma ficção: enquanto partícipes do contexto social, inseridos em uma coletividade específica, as ações resultam da síntese entre as necessidades humanas (históricas e sociais) e as do contexto histórico-cultural, político e econômico em que se inserem. “... a crescente desumanização do trabalho humano em geral e a erosão de seu aspecto potencial criador, sob a divisão do trabalho e, em particular, sob as relações de produção na sociedade capitalista, obscureceu a natureza real do trabalho pela sua forma pervertida." (Wolff, 1982, p. 30). Nesse sentido, restringese a imaginação criativa humana. Partindo desse pressuposto, o sujeito e sua atividade necessariamente precisam ser compreendidos na trama complexa em que se constituem/desenvolvem. A sociedade capitalística, pautada por relações de dominação e subordinação, aparentemente garante espaço para o imaginar e valoriza a ação criativa. No entanto, alguns sujeitos são expropriados da condição de protagonistas de suas próprias histórias de vida e da possibilidade de criar, embora sejam, ainda assim, sujeitos. Sujeitos não somente na condição de sujeitados à ordem social que os constitui e que por eles é constituída, mas também na daqueles 
que pautam suas interações a partir do embate existente entre a realidade de que se apropriam e do(s) modo(s) pelo(s) qual(is) a significam. Qual a conseqüência disso?

Inexoravelmente, observa-se que quanto menor a possibilidade do homem intervir no processo de sua atividade, menor também serão as chances dele imaginar um curso diferente para a mesma, pois quanto mais alienado estiver, menos possibilidades são oferecidas à sua fantasia (Petrovski, 1979). Para ser criativo é preciso explorar o mundo com imaginação,

"Em tal sentido a imaginação adquire uma função de suma importância na conduta no desenvolvimento humano, convertendo-se em meio para ampliar a experiência do homem que, ao ser capaz de imaginar o que nunca viu, ao poder conceber, baseando-se em relatos e descrições alheias ao que não experimentou pessoal e diretamente, não está fechado no círculo estreito de sua própria experiência, mas sim pode distanciar-se muito de seus limites assimilando, com ajuda da imaginação, experiências históricas ou sociais alheias. Desta forma a imaginação constitui uma condição absolutamente necessária para quase toda função cerebral do ser humano." (Vygotsky, 1990, p. 20)

\section{Criar: Uma Forma de Reorganizar o Existente}

A imaginação permite ao homem transformar realidade, via combinação inusitada de seus elementos, o que confirma o fato de que criar está intimamente relacionado às experiências do sujeito. Ganha destaque nesse processo a possibilidade de ver o diverso, o diferente, estranhando o conhecido. Olhar o cotidiano enxergando nele a possibilidade do diferente é, sob o ponto de vista do estudo da atividade criativa a que nos propomos, condição sine qua non para o desenrolar do processo.

O cerne da questão da criatividade parece estar em como o sujeito, através da combinação de elementos de seu cotidiano, produz o inesperado. Como se formam tais combinações? $\mathrm{O}$ que lhe permite estabelecer tais vínculos? $\mathrm{Na}$ busca de respostas a tais questionamentos retomamos a tese de Vygotsky (1990) sobre o processo da imaginação criadora. Vygotsky o descreve como um ciclo que se origina nas experiências do sujeito e que voltará a essa realidade, transformando-a. O primeiro passo seria a percepção do sujeito do que o circunda e de si mesmo, resultante do processo de apropriação das significações: "Constituinte do signo e, portanto, de ordem simbólica - ambas produções sociais - a significação não pertence nem a ordem das coisas nem a de suas representações, mas a ordem da intersubjetividade anônima, em que, ao mesmo tempo que é por ela

Psicologia: Reflexão e Crítica, 2000, 13(3), pp.539-547 constituída é constituinte de toda subjetividade." (Pino, 1992, p. 322)

O processo de mediação semiótica abarca, nesse sentido, a esfera na qual, no contexto da intersubjetividade, os sujeitos se apropriam das significações produzidas/ reproduzidas/ modificadas socialmente. O papel da linguagem enquanto constitutiva do sujeito aparece como central para a compreensão do modo pelo qual, no movimento de tornar próprias as significações sociais de determinada atividade, enseja-se a oportunidade para que o sujeito manifeste a idiossincrasia de sua construção simbólica do universo cultural, no contexto em que se encontra inserido (Pino, 1992). Em outras palavras: entendemos que o diferencial para a criação, entendida como re-arranjo de elementos pré-existentes, reside não só, mas também, no modo pelo qual determinado sujeito se apropria, via linguagem, daquilo já significado socialmente.

A percepção enquanto função psicológica superior jamais é direta, é sempre mediada. Além disso, tendo em vista a base afetivo-volitiva do pensamento e o fato do sujeito e seus atos serem social e historicamente localizados, devemos considerar que este percebe o que pode, o que quer e o que consegue, considerando suas necessidades, história de vida, interesses, preferências e, ainda, suas possibilidades. Porém, se aquilo de que eu me aproprio são as significações e se essas não estabelecem um vínculo especular com o vivido, já que são construídas e des-construídas social e culturalmente, as experiências podem resultar em sentidos diversos, as imagens podem ser desmembradas, alguns traços das experiências mantêm-se na memória, outros se perdem. Esse desmembramento, possível graças à inexistência de uma consciência total das vivências pelo sujeito e o modo único pelo qual esse as significa, fornece elementos em princípio desconexos que, relacionados a outros tantos oriundos de outras experiências, são modificados. Afinal, as imagens e suas significações não permanecem inalteradas. Com novas experiências estas vão se transformando, mesclando, de-formando, re-elaborando.

Esse processo de relacionar elementos até então desconexos é justamente o que confere ao produto da atividade um caráter inusitado. A esse respeito, Vygotsky (1990) destaca que a fantasia apoia-se na memória, dispondo de seus dados e, a partir destes, forma novas combinações. De acordo com este autor, entendemos a memória não enquanto lembranças figurativas de um vivido desmembrado mas a memória enquanto registro de imagens/experiências significadas e significativas que, por isso, não conferem a íntegra do vivido. Assume uma lógica que não a da realidade em si mas a da realidade 
significada, uma vez que a primeira é intangível graças à mediação semiótica introduzida via linguagem pelo sujeito.

Então, qual seria a particularidade da imaginação criadora? Para Petrovski (1979) seria a forma como junção de traços descolados, pelo sujeito, de sua experiência, desvia-se do curso habitual de composições. Um aspecto que merece atenção diz respeito ao que move todo esse processo. O que faz com que os sujeitos passem a unir imagens, traços de experiências, de forma produzir algo diferente do que até então existia? Vygotsky (1990) ressalta a questão da necessidade:

"O ser que se encontre plenamente adaptado ao mundo que o cerca, nada poderia desejar, não experimentaria nenhum afã e certamente nada poderia criar. Por isso na base de toda ação criadora reside sempre a inadaptação, fonte de necessidades, sonhos e desejos (...) a existência de necessidades ou sonhos põe, assim, em movimento o processo imaginativo" (p. 35-36)

Vazquez (1973, citado por Wolff, 1982) também traz a questão da necessidade inexoravelmente ligada às criações/produções humanas:

"Como ser humano natural, o homem continua a vivet no reino da necessidade; mais precisamente, quanto mais humano ele se torna, maior o número de suas necessidades humanas. Essas necessidades ou são necessidades naturais (fome, sexo etc) humanizadas quando os instintos tomam forma humana, ou são necessidades novas, criadas pelo próprio homem no curso de seu desenvolvimento social (...) Sob o imperativo das necessidades humanas, o homem deix de ser passivo, e a atividade torna-se essencial a sua existência (...) As necessidades humanas caracterizam o homem como ser ativo e sua atividade consiste em criar um mundo humano que não existe por si mesmo, fora do homem.” (p. 29)

A necessidade possibilita-nos compreender o que desencadeia a atividade criadora, no entanto, apenas esta categoria não é suficiente para explicar tão complexo processo. A esse respeito, Petrovski (1979) considera que o sujeito percebe a realidade "através de um filtro de estado emocional". Vygotsky (1990) também teoriza sobre a possibilidade do sentimento ser um centro combinatório de imagens, isto é, tudo o que em nós desperta um sentimento comum tende a unir-se aind que não haja semelhança aparente. Nas palavras desse autor, um mesmo signo funciona como aglutinante de elementos heterogêneos: "as imagens da fantasia prestam também linguagem interior a nossos sentimentos selecionando determinados elementos da realidade e combinando-os de tal maneira que respondam a nosso estado interior de ânimo e não à lógica exterior destas próprias imagens." (p.21)

Temos pensado que o processo de apropriação das significações seria o agente aglutinante dos mais diferentes elementos que pautam o viver dos sujeitos. Como a significação abarca não somente aspectos de ordem cognitiva, mas também emocional e perceptual, estabelecer novas relações, característica da imaginação criadora, é resultado das emoções, idéias e aspirações que predominam em um determinado momento e que constituem as necessidades do sujeito. A significação caracterizaria assim, os diversos vínculos estabelecidos pelos sujeitos e, sendo esta completamente imprevisível, as possibilidades de produção/criação humana configuram-se, além de ilimitadas, como singulares.

Podemos ainda nos questionar: o que explicaria, além da necessidade, o fato de alguns sujeitos formarem vínculos inesperados e outros reproduzirem o já posto? A reprodução a qual questionamos não significa a produção do idêntico, mas a manutenção das características plásticas do produto da atividade, já que entendemos que todo trabalho traz as peculiaridades do fazer do sujeito que o engendra e, além disso, ainda que as características plásticas se mantenham, as significações que emergem não se conservam nos diferentes sujeitos a despeito da sua história e de seu contexto. Isto posto, cabe retornar à pergunta inicial: por que alguns sujeitos criam o inesperado enquanto outros reproduzem o já conhecido?

No momento em que o sujeito se prende a padrões estéticos, segue regras cristalizadas e socialmente partilhadas, fica sob a égide de normas grupais coercitivas partilhadas pelo seu grupo de referência, o que torna mais difícil romper com o existente. A possibilidade de liberarse de tais ditames é, pois, condição demarcadora da abrangência da criação, ou seja, do quão inusitada ela será. A essa possibilidade relaciona-se outra, a do sujeito enxergar-se enquanto sujeito da ação, isto é, aquele que pode imprimir mudanças no contexto em que se insere. Referimo-nos à versatilidade e flexibilidade do sujeito no sentido de contrapor-se ao que já é conhecido, inovando.

Pelo que vimos apresentando até o momento, é possível entender que essa versatilidade não é algo inerente ao sujeito mas produzida socialmente, posto que originada/compartilhada no/com o grupo de referência. Do contrário, estar-se-ia novamente enaltecendo o produtor/artista/criador em sua originalidade por contrapor-se ao já conhecido. Esta linha de pensamento, além de considerar o sujeito como causa e conseqüência de si mesmo, isola o artista/produtor tornando-o, de certa forma, marginalizado ou, se obtiver o "reconhecimento social" de sua obra, eternizado. 


\section{O Enredar-se no Rendar e a Trama Tecida a partir} daí...

Temos falado até o momento em como se desencadeia a atividade produtora/criadora no sujeito, mas não devemos nos esquecer de como o resultado dessa atividade retorna ao contexto de onde emergiu, quais as suas conseqüências tanto para o sujeito produtor quanto para os demais sujeitos com quem convive. Abordaremos essas questões a partir de alguns dados da pesquisa que vimos desenvolvendo. A atividade criadora a que dedicamos nossas análises materializa-se em um produto final - a renda de bilro. Para compreender a importância de estudar o produto da atividade no processo de criação retornamos a Vygotsky (1990) pois, segundo este autor, o círculo da atividade criadora só se fecha quando esta assume forma material. Assim, ela existirá no mundo, voltar-se-á sobre o próprio sujeito da ação, impulsionará novas necessidades que, por sua vez, poderão resultar em novas criações, caracterizando assim um vínculo entre imaginação e realidade. O caráter social de toda e qualquer criação humana afirma-se pelo interjogo existente entre o produto da atividade criadora e as novas significações que este engendrará, tanto para o autor/criador, como para os sujeitos que tomarão contato com a produção.

A obra resultante não se caracteriza como algo estático e acabado mas sim como um campo de batalha de novas significações. Wolff (1982) teoriza sobre a importância do "papel ativo do leitor/público na construção do significado da obra cultural" pois é ilimitado o campo das significações que a obra engendrará. "A obra é vista agora como um diálogo entre o autor e o leitor, e a interpretação é considerada como provisória e situacionalmente específica." (p. 135)

Resgatando a contribuição de Vygotsky (1990), podemos afirmar que esse diálogo é fundante do próprio processo de criação, posto que há uma relação inexorável entre sujeito e contexto social: a obra criadora apoia-se, sempre, sobre formas existentes e em necessidades que são historicamente produzidas. Toda criação contém em si um coeficiente social. "Nesse sentido não há invenções individuais no sentido estrito da palavra, em todos permanece sempre alguma colaboração anônima." (Vygotsky, 1990, p. 37-38)

Ao produzir novas significações a obra não só fala do sujeito produtor e do contexto de onde emergiu mas também constitui o sujeito que a produziu, bem como aquele que de sua significação se apropria. Assim, ao mesmo tempo em que o sujeito produz a obra, é produzido pelas significações que essa engendra. Necessariamente, a atividade criadora, além de resultar Psicologia: Reflexão e Crítica, 2000, 13(3), pp.539-547 na materialidade da obra, reverte-se na constituição do sujeito que a construiu. Nesse sentido, entender a atividade criadora a despeito das modificações pelas quais o sujeito vai passando à medida que materializa seus desejos é limitante da compreensão dos processos psicológicos que subjazem à atividade criativa, pois focaliza-se apenas a produção da obra, esquecendo como o sujeito que a produziu é paulatinamente constituído. Esse diálogo do sujeito em relação ao contexto no qual se insere e a obra que daí resulta, marcado pela produção/ socialização/ apropriação de significações, será apresentado a seguir através do movimento de uma aprendiz de renda de bilro.

O Passar dos Anos pode ser visto no Passar dos Bilros..

A renda de bilro chegou ao sul do Brasil por volta de 1748/1749, trazida pelos imigrantes açorianos vindos em busca de melhores condições de vida. A expectativa de deixar para trás a miséria e a fome, no entanto, logo foi confrontada com a dura realidade. Aqui chegando, ao invés de encontrarem a "terra prometida", os imigrantes tiveram que re-editar os costumes que até então caracterizavam sua cultura, como forma de garantir a sobrevivência. Esta re-edição dos usos e costumes, resultante das condições históricas, sociais e geográficas em que se encontravam, perpassou vários campos que caracterizam a vida cotidiana de um grupo social, a saber: gastronomia, habitação, vestuário, atividade econômica folclore e tradição.

A atividade de tecer a renda de bilro, como não poderia deixar de ser, também foi modificada. Praticada, a princípio, para produzir peças ornamentais de casas e igrejas, com o decorrer do tempo e as dificuldades econômicas, passou a ser vista como meio para obter subsídios para complementar o orçamento familiar. A renda de bilro ultrapassa, assim, o âmbito do folclore e das tradições e integra o rol das atividades econômicas desse grupo social. Os imigrantes açorianos passam, então, a produzir e reproduzir a renda enquanto atividade cultural e, concomitantemente, econômica - sendo que a reprodução tem, nesse momento, o objetivo de zelar pela manutenção dos padrões estéticos até então aceitos e ensinados. Seguindo a tradição, a família de Nice, sujeito investigado, passa a confeccionar a renda nesta dupla dimensão.

Nascida na década de 60 , Nice cresceu vendo sua mãe e irmãs dedicarem boa parte do dia à atividade e

${ }^{3}$ Para maiores informações a este respeito recomenda-se a leitura do Capítulo 1 da tese de Zanella (1997). 
buscando obter lucro com a venda aos turistas das peças que produziam. Sendo hoje uma mulher adulta, com nível de escolarização superior - formada em biblioteconomia - Nice identifica em sua história diferentes momentos em relação à renda e ao seu rendar.

Com poucos anos de vida demonstrou interesse em aprender a manusear os instrumentos técnicos com que se tece a renda: almofada, piques, linha, alfinetes e bilros ${ }^{4}$. $O$ interesse de Nice pela renda era, na verdade, resultante da curiosidade pelo novo. "... Eu tive aquele momento de curiosidade, que eu acabei aprendendo uns pontos e nunca mai assim, né...” Nessa etapa ela aprende alguns pontos básicos da renda - perna-cheia, trança e meio ponto - e chega a tecer peças pequenas que são postas à venda. Na entrevistas realizadas durante a etapa de coleta de dados da pesquisa, Nice relata a importância deste momento em sua trajetória na atividade: a apropriação do significado do lucro a partir da venda de uma peça produzida por ela, assim como o reconhecimento de seu trabalho, são destacados.

"Passando a curiosidade, claro que eu não queria ficar sentada numa almofada fazendo renda, né? Mas depois veio uma história de que era gratificante tu tirar um trabalho da almofada e vender, isso era uma coisa que eu me lembro que era legal, e daí no começo eu fiz uma renda que era horrorosa era um amarelo-ouro (risos) e que alguém levou, assim, nossa eu fiquei super feliz!"

Tendo como atribuição na família o trabalho de cuidar da barraca onde ficavam expostas as rendas a serem comercializadas, paulatinamente, Nice passa a manifestar interesse não mais pela atividade em si ou seu produto, mas sim por aqueles que se interessam pela renda - os turistas. A partir do contato com esses, ela entra em contato com diferentes formas de articular a linguagem, diferentes valores, interesses e modos de viver.

"E pras pessoas novas era pra gente muito curioso, né, era muito novo. Nós éramos muito caipiras (risos) prás pessoas, na realidade, imagina, ... o meu pai tinha uma vaca ali quase na beira da estrada, as pessoas tomavam leite em caneco, então isso prás pessoas era uma curiosidade e prá nós essa coisa do novo, do carro, do modo de se vestir... e vender era diferente..."

${ }^{4}$ Os instrumentos técnicos utilizados para tecer a renda de bilro são: almofada, de formato cilíndrico, o pique, em que algumas vezes desenhada a peça de renda a ser tecida. A maioria dos piques, no entanto, possui apenas os furos onde devem ser presos os alfinetes para segurar os pontos que compõem cada uma das partes do bordado. A linha, por sua vez, é enrolada nos bilros, peças de madeira com extremidades no formato similar a uma pêra. Estes instrumentos são trocados pelas rendeira com imensa agilidade, produzindo um som característico resultante do contato entre os mesmos.
Sanada a curiosidade e motivada a ajudar o pai a vender leite pelo bairro onde morava, Nice acaba por se afastar do tecer renda e, a partir daí, configura uma trajetória muito singular em relação àquela traçada pela mãe e irmãs mais velhas. Com o passar dos anos e imersa em contexto acadêmico, por ocasião do período de graduação na universidade, Nice exercita importantes movimentos que nos permitem compreender as transformações que engendra em sua história de vida com relação à renda. $\mathrm{O}$ marco dessas mudanças consiste, segundo Nice, no projeto "A Renda sob um Novo Olhar, que passa a desenvolver junto a uma entidade cultural, onde vai trabalhar como funcionária pública da Prefeitura Municipal de Florianópolis, encarregada de organizar o acervo de piques 5 ."...foi aquela coisa de querer fazer, querer criar coisas novas (risos), porque eu sempre tive essa coisa assim da renda sob um novo olhar, né! "

Nice retoma de forma mais intensa sua história com a atividade quando resolve freqüentar aulas de renda, no próprio Casarão da Lagoa, para entender alguns detalhes dos piques que coletava junto à comunidade rendeira. Atendendo, em princípio, a uma necessidade profissional, o aprender a fazer renda paulatinamente assume novas significações e passa a responder a necessidades outras.

“...tinha um acervo de piques de renda, só que não tinha quem os copiasse (...) E daí eu comecei a ver que algumas coisas eu não entendia (...) por que que tinha aquele furo ali? Tinha umas coisas que não se encaixavam. Aí eu comecei a perceber que eu precisava de mais elementos na realidade pra confeccionar os... [piques]"

No processo de aprender a fazer renda, Nice pode ser entendida como uma aluna sui generis de uma professora sui generis, uma vez que ambas dedicam-se à atividade em um contexto outro que não o doméstico, como era tradição (Beck, Costa, Torrens \& Lacerda, 1982), com finalidade outra que não o lucro e a venda para os turistas. Soma-se a isso o fato de que, aprendidos os pontos básicos da renda e após tecê-la com relativa independência, o produto de sua atividade caracteriza-se por apresentar um re-arranjo dos elementos que a compõem, diferenciando-se das rendas tradicionais. Além de colocar em cena novas possibilidades de uso, como ornar o corpo e não apenas a casa, seu trabalho pauta-se em novas maneiras de combinar pontos, na utilização de materiais

5 O acervo de piques foi montado como uma tentativa de preservar os modelos de rendas antigas que já não são mais produzidos pelas rendeiras. Para tanto, Nice recolhia modelos de piques e os copiava manualmente, um a um, de forma a preservar sua integridade, uma vez que o uso repetido e o tempo são identificados por ela e pelas rendeiras como fatores de deterioração dos piques, deformando as proporçoes dos espaços que devem existir entre um ponto e outro da peça a ser tecida. 
diferentes e na produção de novas técnicas, como reutilização de fios e inserção de novas cores. ${ }^{6}$

“... eu me propus a trabalhar com cor, que na renda se trabalha com cores (...) muito neutras (...) então me propus trabalhar com cor, me propus a trabalhar numa coisa de reciclagem de fio, tanto que todos os patuás que eu fiz eles são todos muito emendados, são cheios de nós mesmo, (...) não é uma coisa que foi porque emendou porque terminou a linha, foi intencional, foi uma coisa de que eu estava afim que isso acontecesse, a reutilização dos fios.”

\section{O Processo de Imaginação Criativa em Nice}

A análise da atividade de Nice na renda de bilro nos permite afirmar que, ao confeccionar peças singulares, essa re-significa tanto a função quanto a estética da renda. O seu rendar caracteriza-se pela mistura de cores, reutilização de fios e adoção de objetos para adereço algumas vezes de madeira e osso. Outro aspecto que se destaca em seu tecer são os nós deixados propositalmente à mostra, o que propõe outra estética à renda de bilro. $\mathrm{O}$ aparentemente errado - a emenda à mostra - adquire para Nice uma nova significação, pois as antigas rendeiras, ao tecer suas peças, usavam de toda sua destreza e habilidade para justamente ocultar aquilo que Nice põe em evidência.

A intenção de não esconder emendas demonstra um estilo próprio que supomos encontrar eco em muitas outras propostas que vimos atualmente em áreas distintas. A reutilização de fios traz, ao nosso ver, muitos aspectos implicados que, apesar de não existir menção específica do sujeito a esse respeito, buscamos explicar via preocupação com o meio ambiente, já que se vive na era da reciclagem e transformação intensa de matérias-primas. Da mesma forma, ressaltamos aspectos tanto voltados à economia de material preconizada pela própria artesã no tecer suas peças, quanto ao resultado estético que as emendas produzem. Outro aspecto de seu trabalho, a mistura de cores novas em substituição às tradicionais, materializa as inovações que o sujeito pretende concretizar na renda de bilro.

As peças que confecciona, por sua vez, abrem um novo espaço para a atividade da renda de bilro, ampliam seu campo de consumo aproximando-a do cotidiano das pessoas. Nisso consiste a mola propulsora da atividade criativa de Nice: lançar o produto do seu trabalho em um contexto mais abrangente, o que contribui para que a

${ }^{6}$ Para maiores informações sobre os embates entre Nice/suas produções e as rendeiras/rendas tradicionais ver Zanella, Balbinot e Pereira (1999). Esse capítulo de livro apresenta as resignificações que Nice imprimiu tanto à atividade de fazer renda quanto ao ser rendeira. atividade se mantenha em evidência, fazendo-a sobreviver ao esquecimento em que muitas das tradições açorianas parecem imergir na Ilha de Santa Catarina. Seu interesse em difundir a renda de bilro, mostrando que esta pode se adequar às novas exigências sociais, leva implícito o desejo de que as pessoas possam se interessar em aprender a fazer a renda, atividade que parece estar fadada à extinção.

"É uma coisa legal tu ver na pessoa, sem essa coisa que a renda é só como uma toalha, é claro que é uma coisa bonita fazer toalha, mas essa coisa (...) de tu dá pra tua casa e tu dá para a pessoa um presente faz uma diferença nas peças de renda. Isso sempre me levou a querer fazer alguma coisa que as pessoas possam usar ... fica mais à mostra no sentido pro outro. Ficou legal na pessoa ... eu achei que as pessoas vendo circular, também elas começam a produzir...”

De acordo com os depoimentos deste sujeito ao longo das entrevistas realizadas, observa-se que o que parece mover sua criação é seu interesse pela difusão da atividade e, assim, a sobrevivência da mesma. Há uma razão pela qual Nice deseja que a renda de bilro não desapareça no contexto atual, e esse interesse corresponde ao envolvimento emocional desta com a atividade. Isto significa que o desejo de Nice está implicado também em manter as tradições, o que garantiria que parte da história de seus antepassados e, por conseqüência, de sua própria história, não se apagasse. Somado a isso, as criações de Nice lhe permitem atualizar a atividade, na medida em que ela re-significa a renda de bilro materializando seus propósitos e, ao assim fazer, resgatando-a de um passado distante e fadado ao esquecimento, adequando-a aos novos anseios e necessidades que identifica na contemporaneidade.

Esse envolvimento afetivo com a atividade, no entanto, não é exclusividade sua e, por conseguinte, não necessariamente explica a relação inovadora que estabelece com a atividade. Afinal, é sabido que a maior parte das artesãs tradicionais da renda de bilro também têm um enlace emocional com a mesma. Outro aspecto que corrobora esta consideração é o fato de que a renda é muitas vezes enaltecida na prosa e poesia da Ilha de Santa Catarina' e que Nice destaca em suas palavras: “ ... o que eles chamam dessa coisa de maleabilidade com os bilros que vira uma poesia dospoetas, de tu sentar e de tu não ver os bilros passar..."

O que a diferencia então? Há muitos aspectos a serem considerados. O fato de a renda ser uma atividade muito

${ }^{7}$ Uma das músicas mais difundidas nos meios de comunicação de Florianópolis chama-se Rancho de Amor à Ilba, composta por Cláudio Alvim Barbosa, o "poeta Zininho". Em um de seus versos a renda de bilro é enaltecida através da figura da artesã: "Ilha da moca faceira, da velha rendeira tradicional..." 
trabalhosa e trazer pouco retorno financeiro para quem a confecciona fez com que, nas últimas décadas, as filhas de rendeiras dificilmente aprendessem a atividade. Assim, poucas são as jovens atualmente que aprenderam a tece como suas mães e avós. Estas, por sua vez, lutam pela preservação de sua história, pois continuam exercendo seu trabalho apesar de extremamente penoso e mal remunerado.

Nice também teve outras vivências pouco comuns às rendeiras. Ela teve acesso ao mundo do trabalho realizado na esfera pública quando, ainda criança, foi encarregada de vender a renda para os turistas e, posteriormente, saiu para vender leite com o pai. Estas experiências possibilitaram-lhe conhecer outras formas de relações sociais. Teve também acesso à universidade, onde se enfatiza o desenvolvimento do pensamento abstrato, o estranhamento das situações cotidianas e o exercício do olhar analítico e sintético. Como nenhuma de suas irmãs alcançou a escolarização superior, este aspecto apresentase como diferenciador em sua trajetória de vida se a comparamos com a de outras rendeiras.

Não se trata aqui, no entanto, de estabelecer qualquer relação direta entre escolarização e desenvolvimento de processos de imaginação criativa, uma vez que existem evidências suficientes para desmentir uma possível linearidade nesse sentido. Afinal, é preciso que se reconheça o fato de que a escolarização também produz fracasso, embota a capacidade criadora dos sujeitos ao tentar neutralizar muitas iniciativas significativas no âmbito da criatividade e da arte, em nome da disciplina, ordem do dia e objetivos escolares. Porém, é necessário destacar que a inserção de Nice em contexto acadêmico admite maiores análises, uma vez que suas criações na renda têm relação com outros significados do vocábulo criar: “... educar, crescer, desenvolver-se, nascer...” (Encyclopaedia Britannica do Brasil, 1989, p. 507). Ao compreender o processo educativo enquanto constituinte, porém não determinante do sujeito, demarca-se que esse certamente modifica o leque de possibilidades para cada um. Nesse sentido, a escolarização pode ter oferecido algun elementos para que Nice diferenciasse seu rendar do de outras rendeiras com as quais convive. Dentre os vários aspectos envolvidos neste tema, seria interessante apontar o fato de que a escolarização, ao enfatizar o uso da linguagem, permite ao sujeito ampliar seu conjunto de significações dos elementos que identifica no contexto em que se insere, complexificando sua percepção ao ponto de compor e decompor objetos e atividades em múltiplas unidades formadoras.

Dado que a percepção é sempre contextual, ou seja datada e histórica (Vygotsky, 1992) e que também é ortoscópica - atualiza-se permitindo notar os traços estáveis do objeto que não dependem de circunstâncias casuais - o resgate da história deste sujeito com a atividade e sua inserção em contexto escolar, enquanto tentativa de compreender o movimento de apropriação das significações da renda feito por Nice, tornam-se relevantes para o estudo da atividade criativa engendrada por este sujeito.

\section{Considerações Finais}

A história de vida do sujeito por nós investigado e sua trajetória na renda conferem singularidade às suas produções. Vemos, então, que não é possível descolar as rendas de Nice do contexto histórico-cultural em que foram produzidas, pois tais rendas falam tanto do sujeito quanto do contexto em que este se insere. Neste sentido não se deve pensar no autor/artista como uma genialidade criadora a despeito das condições em que vive e tampouco sacrificar o produtor/criador frente a determinismos sociológicos. Compreender o contexto em que o sujeito se insere, assim como sua história de vida e a história da atividade, é fundamental para a compreensão das significações de que se apropriou o sujeito e das necessidades que o movem a criar.

Há, no entanto, uma ressalva a ser feita. Com as análises aqui tecidas, não se pretendeu esgotar a temática, nem estabelecer relações linearizantes na compreensão do movimento traçado por Nice na atividade rendeira. Tampouco objetivou-se demarcar alguns aspectos desta trajetória como se os eventos narrados houvessem ocorrido em seqüência esquemática no tempo e no espaço. Não nos é possível, enquanto pesquisadoras, e nem seria cabível, tentar precisar todos os aspectos envolvidos no processo criativo de Nice. O interesse foi investigar tal processo considerando sua natureza dialética e entendendo-o como multifacetado e não como uma seqüência estática de passos da "criação".

Criar no sentido de educar, como aponta o dicionário, pode, no processo em análise, ser entendido enquanto meio através do qual Nice se apropria de uma das atividades identificadoras de sua origem cultural. Por outro lado, a resignificação que esta faz ao longo de seu processo de constituição enquanto sujeito que tece renda, torna possível a ela acrescentar a idiossincrasia de seu olhar à renda de bilro. Além disso, permite protagonizar, em sua história de vida, o movimento de mostrar ao outro novas possibilidades de pensar e fazer renda, de maneira a redimensionar e re-editar o real espaço que esta vem ocupando nos últimos tempos. 
Vygotsky (1990) enfatiza que a riqueza e variedade das experiências possibilitam outras formas de explorar o mundo com a imaginação. O contexto que rodeia Nice é significado por ela de maneira que, dada a variedade e quantidade de informações ali existentes, pode-se ver neste processo complexo e multifacetado que é a criatividade, elementos de sua forma singular de confeccionar a renda de bilro.

O seu movimento em relação à renda de bilro está em consonância com o que Peixoto (1988) informa ao abordar a questão do olhar estrangeiro. Para este autor, o olhar estrangeiro "é aquele que não é do lugar, que acabou de chegar, é capaz de ver aquilo que os que lá estão não podem mais perceber(...) ele é capaz de olhar as coisas como se fosse pela primeira vez." (p.363) Neste sentido, o estranhamento da artesã é manifestação desta sua capacidade de ver a renda e o grupo rendeiro enxergando-os não somente enquanto atividade e contexto culturais, mas sim como algo a ser desvendado, des-coberto e re-criado. $\mathrm{O}$ estrangeiro seria aquele que “...reintroduz imaginação e linguagem...” (p.363)

Nice pode ser vista como o estrangeiro que "volta a sua nova terra natal", figura metafórica que utilizamos para delinear a junção dos propósitos da rendeira ao contexto do qual emergiram: o grupo rendeiro da Lagoa da Conceição na Ilha de Santa Catarina. Fala-se em "nova terra natal" no sentido de que ao ressignificá-la, Nice não mais tem acesso ao que era até então, posto que sua representação simbólica está re-editada, é outra, apesar de sempre guardar um substrato que a identifica com a significação anterior, como uma construção ininterrupta e complexa: o processo de sua constituição enquanto sujeito rendeiro.

Segundo Peixoto (1988), ainda, "Uma das encarnações mais recorrentes do estranho, do recém-chegado, é aquele que retorna.(...) Depois de fugir deste mundo em que nada mais tem valor, ele volta para resgatar as figuras e paisagens banalizadas de nosso imaginário, para tirar dele uma identidade e um lugar.”(p. 363) Estudar o processo de constituição do sujeito e suas interfaces, dentre as quais a criatividade, além de pensar a busca de Nice por um lugar no grupo rendeiro, torna possível entender o fato de que seu movimento foi, em verdade, a saída e o retorno ao contexto em que se insere de maneiras diferenciadas ao longo do tempo, da história de seu movimento de significações, de tal modo a tornar possível a este sujeito concretizar sua visão de si e da renda a partir de parâmetros até então inusitados. Partindo do que era o habitual, o costumeiro e o aceitável, a artesã descola seu processo identitário de uma condição única, tornando-o assim, inusitado, conquanto compartilhado.

\section{Referências}

Beck, A., Costa, C. M., Torrens, J. C. \& Lacerda, E. P. (1982). Roça, pesca, renda: Trabalho feminino e reprodução familiar. Boletim de Ciências Sociais, 23, 5-39.

Benjamin, W. (1996). Obras escollidids: Magia e técnica, arte e politica (6.ed.). São Paulo: Brasiliense.

Ferreira, A. B. de H. (1997). Novo Dicionário da Lingua Portuguesa (2 ed.). Rio de Janeiro: Nova Fronteira.

Encyclopaedia Britannica do Brasil (1989). Dicionário Brasileiro da Lingua Brasileira (11 ed.). São Paulo: Melhoramentos.

Guatarri, F. \& Rolnik, S. (1986). Micropolitica: Cartografias do desejo (2 ed.). Petrópolis: Vozes.

Peixoto, N. B. (1988). O olhar do estrangeiro. Em A. Novaes (Org.), O olhar (pp. 361-365) Rio de Janeiro: Companhia das Letras.

Petrovski, A. (1979). Psicologia general. Havana: Pueblo y Educación.

Pino, A. (1992). As categorias de público e privado na análise do processo de internalização. Educacão e Sociedade, 42, 315-327.

Vygotski, L. S. (1990). La imaginacion y el arte na infancia. Madrid: AKAL. Vygotski, L. S. (1992). Obras escogidas. Madrid: Visor Distribuiciones. Wolff, J. (1982). A producão social da obra de arte. Rio de Janeiro: Zahar. nella, A. V. (1997). O ensinar e o aprender a fazer renda: Estudo sobre a apropriaçã da atividade na perspectiva histórico-cultural. Tese de Doutorado nãopublicada, Curso de Pós-Graduação em Psicologia da Educação,
Pontifícia Universidade Católica de São Paulo. São Paulo, SP.

Zanella, A V., Balbinot, G. \& Pereira, R.S. (1999). Tu me ensina a fazer renda que eu te ensino a ... inovar: Um estudo do constituir-se rendeira à luz da psicologia histórico-cultural. Em A. F. Silveira, C Gewehr, L. F. Bonin \& Y. L. M. Bulgagov (Orgs.), Cidadania e participaşão social (pp. 183-194). Porto Alegre: ABRAPSOSUL

Recebido em 09.08 .1999 Primeira revisão em 14.01.2000 Aceito em 23.02.2000

Sobre as autoras:

Andréa Vieira Zanella é Psicóloga, Mestre e Doutora em Psicologia da Educação (PUC/SP), Professora Adjunto da Universidade Federal de Santa Catarina, Coordenadora do Laboratório de Educação e Saúde Popular, Pesquisadora CNPq

Gabriela Balbinot é Psicóloga formada pela Universidade Federal de Santa Catarina. Desenvolveu, durante dois anos, pesquisa junto ao Laboratório de Educação e Saúde Popular da Universidade Federal de Santa Catarina, como acadêmica bolsista pelo Programa PIBIC/CNPq-BIP/UFSC.

Renata Susan Pereira é Acadêmica de Psicologia da Universidade Federal de Santa Catarina. Desenvolve, desde de 1997, pesquisas junto ao Laboratório de Educação e Saúde Popular da Universidade Federal de Santa Catarina como bolsista pelo Programa PIBIC/CNPq-BIP/UFSC.

Psicologia: Reflexão e Crítica, 2000, 13(3), pp.539-547 


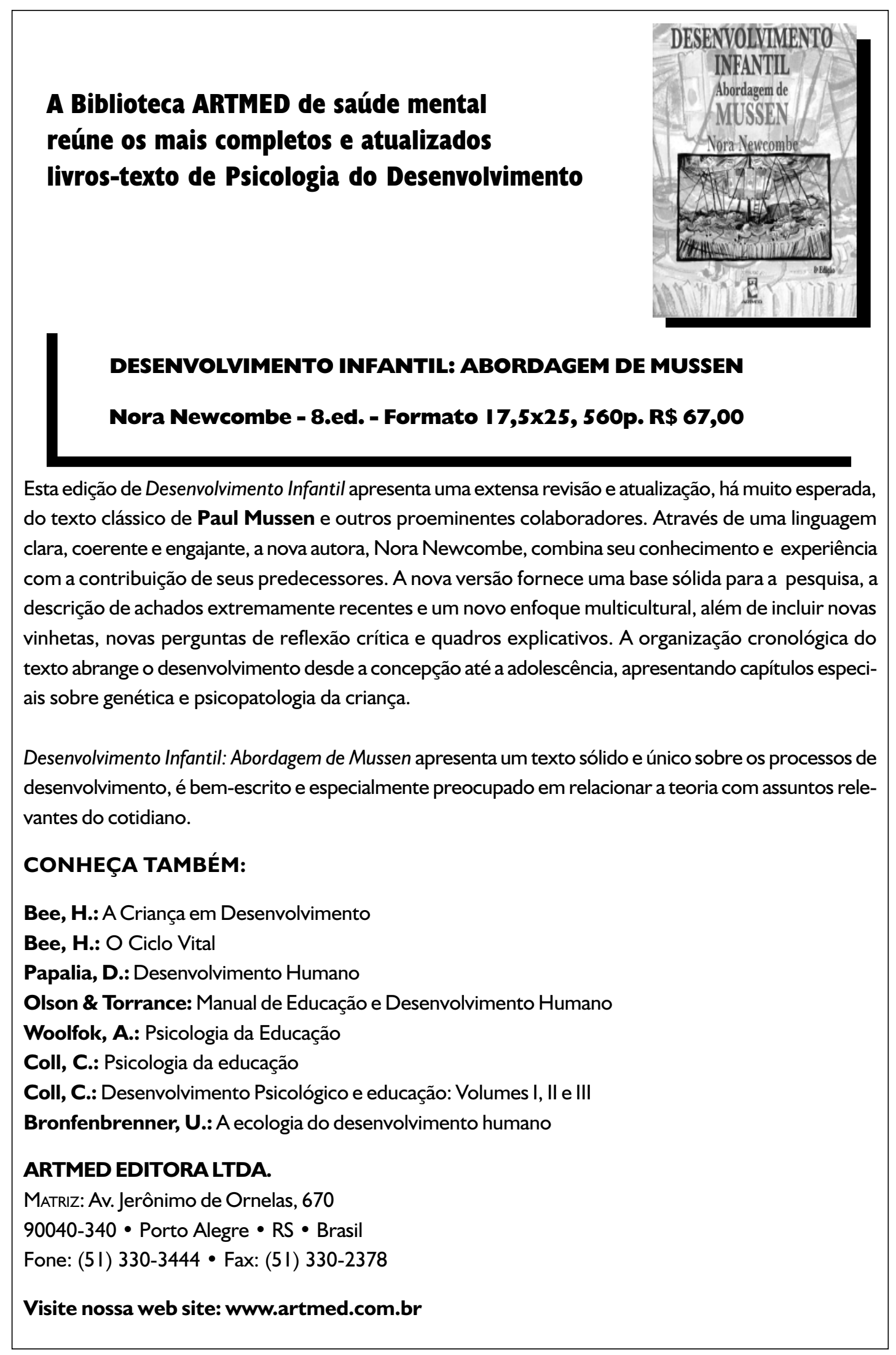


Obituário

\title{
Paul Mussen
}

\author{
Nancy Eisenberg ${ }^{12}$ \\ Arizona State University, EUA
}

Paul H. Mussen, um pioneiro no campo da psicologia do desenvolvimento, faleceu aos 78 anos no dia 7 de julho último, de câncer. Um dos primeiros psicólogos do desenvolvimento, o Dr. Mussen (com John Conger) escreveu o texto clássico "Child Development and Personality" (1956), que foi a obra padrão na área por 30 anos. Ele fazia parte de um pequeno grupo de psicólogos do desenvolvimento, que levou a área de uma orientação behaviorista, de estímulo-resposta, para uma abordagem focada na socialização parental e questões de internalização. Ele editou duas edições da "biblia" da área, o "Handbook of Child Psychology" (publicado em 1970 e em 1983), além de muitos outros livros, entre os quais "The Psychological Development of the Child" (1963), "The Roots of Caring, Sharing and Helping" (com Nancy Eisenberg, 1977) e "The Roots of Prosocial Behavior in Children" (com Nancy Eisenberg, 1989). Muitos de seus livros foram traduzidos para outras línguas e tiveram múltiplas edições.

Paul Mussen nasceu em 21 de março de 1922, em Paterson, New Jersey, Estados Unidos. Ele cresceu em Connecticut e freqüentou a Universidade de Connecticut, em Storrs, até receber uma bolsa da Universidade de Stanford em 1939. Durante a II Guerra Mundial, Mussen serviu como um guarda-marinha no serviço de Inteligência Naval da marinha americana em Washington, D.C, no Hawaii e em San Francisco. Ele completou seu Ph.D. em Psicologia na Universidade de Yale em 1949, fazendo amizades que durariam por toda a vida com colegas e professores, inclusive com seu colaborador John Conger. Inicialmente ele trabalhou na Universidade de Wisconsin, em Madison, de 1949 a 1951, e após na Obio State University em Columbus até 1955. Nesta universidade ele conheceu e se casou com Ethel Foladare, uma estudante de pós-graduação que lá completou seu doutorado.

Em 1956, Mussen foi para a Universidade da California em Berkeley onde trabalhou até sua aposentadoria (1986). Nesta universidade, ele foi diretor do Instituto de Desenvolvimento Humano, de 1971 a 1980 e retornou de sua aposentadoria, em 1987, para

${ }^{1}$ Endereço para correspondência: Arizona State University, Tempe, Arižona, $E U A$

2 A editora agradece ao Prof. Claudio Simon Hutz, a tradução para o Português. atuar como como diretor pró-tempore deste Instituto. Ele recebeu uma bolsa da Fundação Fulbright, em 1960, para fazer pesquisa em Florença, na Itália, e, em 1968, foi escolhido para ser Fellow do Centro de Estudos Avançados em Ciências Comportamentais em Stanford.

Mussen lecionou e deu consultorias para universidades em vários países da Europa, Egito, Nigéria, Israel e Oriente Médio, Índia, Paquistão, Japão, Nova Zelândia e Austrália. Ele foi um dos primeiros professores americanos a lecionar na China, após a Revolução Cultural. Posteriormente, ele desempenhou um importante papel na revitalização dos programas de psicologia social e do desenvolvimento nas universidades chinesas.

Por ser uma fonte de força, liderança e de apoio a muitos em sua profissão, Mussen atuou como membro da unidade revisora de propaganda direcionada a crianças do Better Business Bureau por muitos anos, elevando os padrões de publicação e propaganda em programas de televisão direcionados a crianças. Ele foi também presidente da Western Psychological Association de 1973 a 1974, e da Divisão de Psicologia do Desenvolvimento da American Psychological Association de 1977 a 1978.

Recentemente, entre a coleção de livros que ele tanto amava, e com uma vista de São Francisco e da Golden Gate, ocorreu uma reunião informal de amigos, vizinhos, familiares e colegas em sua casa para expressar afeição e estima a esse humanista espirituoso. Muitos dos que conheceram Paul exercendo papéis profissionais, tiveram o privilégio de sua amizade. Ele não foi apenas meu mentor, mas também meu amigo pessoal. Paul era uma pessoa calorosa, envolvente, que dava liberalmente seu tempo, conselho e apoio a todos. Ele tinha um gosto pela vida que era contagiante. Ele fará muita falta para seus amigos, colegas, ex-alunos e familiares.

\section{Referências}

Eisenberg, N. \& Mussen, P. (1989). The roots of prosocial behavior in children Cambridge: Cambridge University Press. Mussen, P. (Org.). (1970). Carmichael's manual of child psychology. New York: Wiley.

Mussen, P. (Org.). (1983). Handbook of child psychology. New York: Wiley. Mussen, P. (Org.). (1963). The psychological development of the child. New York: Wiley.

Mussen, P. \& Conger, J. (1956). Child development and personality. New York: Harper.

Mussen, P. \& Eisenberg, N. (1977). The roots of caring, sharing and belping. San Francisco: Freeman. 


\section{Paul Mussen}

Nancy Eisenberg

Arizona State University, EUA

Paul H. Mussen, a pioneer in the field of developmental psychology, died at 78 On July 7, 2000 from cancer. One of the early developmental psychologists, Dr. Mussen (with John Conger) wrote the classic text, "Child Development and Personality"(1956), which was the standard in the field for 30 years. He was among a small group of developmentalists who moved the field from a behaviorist, stimulus-response orientation to a focus on parent socialization and issues of internalization. He edited two editions of the "bible" of the field, "The Handbook of Child Psychology" (published 1970 and 1983), and published numerous other books, including "The Psychological Development of the Child" (1963), "The Roots of Caring, Sharing and Helping" (with Nancy Eisenberg, 1977), and "The Roots of Prosocial Behavior in Children" (with Nancy Eisenberg, 1989). Many of his books were translated into other languages and went through multiple editions.

Paul Mussen was born March 21, 1922, in Paterson, New Jersey. He grew up in Connecticut and attended the University of Connecticut at Storrs until he received scholarship to Stanford University in 1939. Mussen served as an ensign in Naval Intelligence in the Navy in Washington, D.C, Hawaii, and San Francisco in World War 11. He completed his $\mathrm{PhD}$ in psychology at Yale University in 1949, forming lifelong friendships with fellow students and faculty, including his future collaborator, John Conger. He first taught at the University of Wisconsin, Madison, from 1949-51 and then at Ohio State University in Columbus until 1955, where he met and married Ethel Foladare, a graduate student who earned her PhD at Ohio State.

Dr. Mussen moved to University of California, Berkeley in 1956, where he worked until retirement (1986). At UC Berkeley, he served as director of the Institute of
Human Development from 1971-80 and returned from retirement to serve as acting director in 1987 . He received a Fulbright Award in 1960 for research in Florence, Italy, and in 1968 was selected as a Fellow of the Center for Advanced Study in the Behavioral Sciences at Stanford.

Dr. Mussen lectured and consulted at universities throughout Europe, Egypt, Nigeria, Israel and the Middle East, India, Pakistan, Japan, New Zealand and Australia. He was one of the first American professors to teach in China following the Cultural Revolution. He later played an role in revitalizing the programs on social and developmental psychology in Chinese universities.

A source of strength, leadership and support to many in his profession, Mussen served as a member of the children's advertising review unit of the Better Business Bureau for several years, upholding standards of writing and advertising on children's television. He was president of the Western Psychological Association from 1973-74 and the American Psychological Association's division of developmental psychology from 1977-78.

Amid his beloved collection of books, facing a view of San Francisco and the Golden Gate, an informal gathering of friends, neighbors, family, neighbors, friends, and colleagues at his home recently voiced affection and esteem for the witty humanist. Many who knew Paul in professional roles had the privilege of his friendship. He was not only my mentor, but my close friend. Paul was a warm, engaging person who gave freely of his time, advice, and support to all. He had a zest for life which was contagious. He will be sorely missed by his many friends, colleagues, and past students, and his family.

Texto publicado a convite da Editora Profa. Sílvia H. Koller, em homenagem a um dos principais nomes da Psicologia do Desenvolvimento. Recebido em 16.08.2000

Sobre a autora:

Nancy Eisenberg é Professora Regente de Psicologia, na Arizona State University, Tempe, Arizona, EUA. 


\section{Normas para Publicação}

\section{Linha Editorial}

A Revista Psicologia: Reflexão e Crítica é uma publicação semestral de trabalhos originais: relatos de pesquisas, estudos teóricos, revisões críticas da literatura, comunicações breves sobre pesquisas, relatos de experiência profissional, notas técnicas, resenhas, notícias, na área de Psicologia. Todo o processo editorial da revista Psicologia: Reflexão e Crítica visa a apresentar à comunidade científica um texto que reflita uma contribuição significativa para a área.

As Normas de Publicação da revista Psicologia: Reflexão e Crítica baseiam-se no Publication Manual of the American Psychological Association - APA (1994, $4^{a}$ edição), no que diz respeito ao estilo de apresentação do manuscrito e aos aspectos éticos inerentes à realização de um trabalho científico. Algumas adaptações do Manual foram realizadas, por algumas revistas brasileiras, e adotadas pela Psicologia: Reflexão e Crítica, para adequação das normas à língua portuguesa.

Por exemplo, a utilização das expressões:

"e colaboradores", ao invés de "et al.", no texto.

"Org.", para indicador o editor ou organizador de um livro, ao invés de "Ed.", na seção de referências.

"Em", para indicar inclusão em capítulo de livro, ao invés de "In", na seção de referências.

Passos do Processo Editorial

Antes de submeter um Manuscrito

Siga os passos abaixo em detalhe, lembrando que a boa apresentação, além de assegurar a credibilidade de seu estudo, agilizará o processo editorial:

Solicite a um de seus colegas de área ou de depar-

tamento, a apreciar seu manuscrito e fazer comentários críticos sobre ele.

Revise, cuidadosamente, seu manuscrito com

relação à correção do Português e da digitação.

Verifique se cada detalhe das Normas de Publi-

cação da revista foram atendidos. Consulte o Manual, em caso de dúvida.

Anexe uma carta de encaminhamento ao editor,

incluindo, impreterivelmente:

autorização para o processo editorial de seu manuscrito;

garantia que todos os procedimentos éticos exigidos foram atendidos;

concessão dos direitos autorais de seu manuscrito à

Psicologia: Reflexão e Crítica;

assinatura de todos os autores do estudo.
Submissão do Manuscrito

As submissões deverão ser encaminhadas por correio. Não serão aceitos manuscritos por fax ou por correio eletrônico. O envelope endereçado à revista Psicologia: Reflexão e Crítica deverá conter:

Manuscrito original em quatro (4) cópias impressas. - Carta de encaminhamento indicando a categoria na qual seu manuscrito se insere: relatos de pesquisas, estudos teóricos, revisões críticas da literatura, comunicações breves sobre pesquisas, relatos de experiência profissional, notas técnicas, resenhas, notícias.

- $\quad$ Disquete (MSWord ou WP), com figuras e tabelas em arquivos separados.

\section{Procedimentos da Comissão Editorial}

O processo de revisão editorial só terá início se o encaminhamento do manuscrito obedecer às condições acima. Caso contrário, será devolvido aos autores, para adequação às normas, inclusão de cópias, carta ou assinaturas.

Os manuscritos recebidos são, inicialmente, apreciados pelo Editor, que enviará aos autores ma carta ou e-mail comunicando sobre o início do processo editorial. S estiverem de acordo com as Normas mencionadas e sejam considerados potencialmente, como, publicáveis pela revista Psicologia: Reflexão e Crítica serão encaminhados para Consultores ad hoc. Os originais submetidos e disquetes não serão devolvidos.

Os consultores ad hoc serão escolhidos pelo Editor, entre pesquisadores de reconhecida competência na área. Os autores podem auxiliar no processo editorial sugerindo possíveis consultores (pesquisadores qualificados afiliados a instituições, que não as dos autores) na carta de encaminhamento. Psicologia: Reflexão e Crítica encoraja este procedimento, no entanto, a escolha dos consultores será sempre feita pelo Editor, que pode aproveitar ou não as sugestões dos autores. A identidade dos autores e suas afiliações institucionais não será informada aos consultores ad hoc. A identidade dos consultores não será informada aos autores dos manuscritos. Caso um consultor tenha qualquer impedimento de se manifestar sobre algum manuscrito deverá retorná-lo, imediatamente, ao editor.

Os consultores, após análise do manuscrito, rejeitam, recomendam ou aceitam a publicação do manuscrito. Os autores receberão as cópias dos pareceres dos consultores na íntegra. Psicologia: Reflexão e Crítica considera que os autores têm direito 
a conhecer todas as possíveis reações que seu trabalho pode gerar na comunidade científica, durante o processo editorial. Psicologia: Reflexão e Crítica conta com consultores, que são colegas qualificados, e procuram melhorar a qualidade dos textos publicados. Estimulandoos a emitir pareceres críticos e construtivos ao trabalho dos autores.

Caso o manuscrito tenha sido rejeitado, os autores podem ser encorajados a resubmetê-lo. Nestes casos, Psicologia: Reflexão e Crítica recomenda uma revisão cuidadosa do manuscrito, dando atenção aos pareceres dos consultores, antes de reiniciar o processo. Em geral, manuscritos submetidos após uma primeira rejeição, embora recebam uma nova data de início do processo editorial, são encaminhados aos mesmos consultores que revisaram o trabalho anteriormente.

A recomendação para publicação associada a sugestões não implica, necessariamente, a aceitação do manuscrito. As sugestões visam, em geral, a melhorar a clareza ou a precisão do texto. Raramente um artigo submetido não pode ser melhorado. É importante que os autores entendam que solicitações de modificações em um artigo são comuns e rotineiras em todos os periódicos de alta qualidade. As sugestões dos consultores têm por objetivo melhorar o trabalho, para atender às exigências da comunidade científica e da revista, e não devem ser consideradas como críticas pessoais. O autores de manuscritos recomendados para publicação, mas sujeitos a modificações, deverão reformular seu trabalho, visando a alcançar a aceitação final. Se os autores não concordarem com algumas das sugestões dos consultores devem incluir na carta ao editor, para o encaminhamento da versão reformulada, informaçõe sobre as alterações efetuadas e justificativas àquelas não realizadas. Esta carta e o manuscrito reformulado serão encaminhados a um dos Conselheiros Editoriais juntamente com os pareceres dos consultores ad hoc e a versão inicial do manuscrito para uma análise final. Nesta etapa do procedimento, o Conselheiro Editorial terá conhecimento das identidades dos autores e dos consultores.

A função do conselheiro será analisar a versão reformulada do manuscrito, auxiliando o editor a tomar a decisão final sobre a publicação do mesmo. Em sua análise, o conselheiro poderá rejeitar o manuscrito, sugerir novas alterações (quantas vezes considerar necessárias) ou aceitar a versão reformulada que considerar pronta para ser publicada.

A decisão final sobre a publicação de um manuscrito, no entanto, será sempre do editor, que apreciará o parecer do conselheiro e notificará os autores, o mais rapidamente possível, sobre sua decisão, indicando a data prevista, o volume e o número da revista, no qual o artigo será publicado.

Durante o processo de editoração gráfica da revista, o editor reserva-se o direito de fazer pequenas modificações no texto dos autores, para agilizar o processo de publicação. Antes de enviar os manuscritos para impressão final, o editor enviará uma prova gráfica para a última revisão dos autores. Esta revisão deverá ser feita em cinco dias úteis e devolvida à revista por sedex ou por fax. Caso os autores não devolvam indicando correções, o manuscrito será publicado conforme a prova. Os autores receberão um exemplar da revista Psicologia: Reflexão e Crítica por artigo publicado e dez separatas.

\section{Direitos Autorais}

A Revista Psicologia: Reflexão e Crítica possui os direitos autorais de todos os artigos publicados por ela. A reprodução total dos artigos desta Revista em outras publicações, ou para qualquer outro fim, por quaisquer meios, requer autorização por escrito do Editor. Reproduções parciais de artigos (resumo, abstract, mais de 500 palavras de texto, Tabelas, Figuras e outras ilustrações) deverão ter permissão por escrito do Editor e dos autores.

\section{Reprodução de Outras Publicações}

Citações (com mais de 500 palavras), reprodução de uma ou mais Figuras, Tabelas ou outras ilustrações, devem ter permissão escrita do detentor dos direitos autorais do trabalho original para a reprodução especificada em Psicologia: Reflexão e Crítica. A permissão deve ser endereçada ao autor do trabalho submetido. Os direitos obtidos secundariamente não serão repassados em nenhuma circunstância.

\section{Roteiro para Apresentação Formal do Manuscrito}

Para agilizar os serviços de editoração eletrônica utilize WordPerfect ou MSWord para PCs e seja econômico na utilização de comandos. Use sempre a mesma fonte (Times New Roman 12), não utilize negrito, itálico, aspas, marcas d'água ou outros recursos que podem tornar o texto visualmente atrativo, mas que trazem problemas sérios para a editoração. Sublinhe palavras ou expressões que devam ser enfatizadas no texto impresso, por exemplo "estrangeirismos", como self, locus, rapport, etc., e palavras que os autores desejem grifar. Lembre, no entanto, que o Manual APA não recomenda uso de ênfases gráficas e 
grifos no texto, pois podem distrair o leitor e atrapalhar o entendimento do texto.

\section{Partes do Manuscrito}

A apresentação dos manuscritos deve obedecer a seguinte ordem:

\section{Folha de Rosto Identificada}

Título em Português e em Inglês (máximo de 15 palavras). O título deve ser pertinente, claro e pode ser criativo. Deve informar o leitor sobre o objetivo do artigo. Não devem incluir nomes de cidades, países, ou outras informações geográficas.

Título abreviado (máximo 8 palavras)

Nome de cada um dos autores

Afiliação institucional de cada um dos autores (incluir apenas o nome da universidade e a cidade)

Nota de rodapé com endereço completo de um dos autores para correspondência com o editor (incluir CEP, Fone, Fax e E-mail)

Nota de rodapé com agradecimentos dos autores e informação sobre apoio institucional ao projeto.

ATENÇÃO: Como a revisão dos manuscritos é cega quanto à identidade dos autores, a Folha de Rosto Identificada deve ser a única página do manuscrito com o nome e os endereços dos autores. É responsabilidade dos autores verificar que não haja elementos capazes de identificá-los em qualquer outra parte do artigo. A Folha de Rosto Identificada, obviamente, não será encaminhada aos Consultores ad hoc. Psicologia: Reflexão e Crítica não se responsabiliza por procedimentos dos autores que não respeitem a esta norma.

\section{Folha de Rosto sem Identificação}

- Título completo em Português e em Inglês

- Título abreviado

\section{Resumo}

- Resumo em Português, com 100 a 150 palavras. No caso de relatos ou comunicações breves de pesquisas, o resumo deve apresentar brevemente os objetivos, método, resultados e discussão do estudo. $\mathrm{O}$ resumo não precisa, necessariamente, incluir informações sobre a literatura da área e não devem ser incluídas referências no resumo. O objetivo deve ser claro, informando, caso for apropriado, qual o problema e as hipóteses do estudo. Para os relatos de pesquisa, o método devem oferecer informações breves sobre os participantes, instrumentos e procedimentos especiais utilizados. Apenas os resultados mais importantes, que respondem aos objetivos da pesquisa devem ser mencionados no resumo. O resumo é uma das partes mais importantes do seu manuscrito.

- Palavras-chave em Português (no mínimo 3 e no máximo 5, em letras minúsculas e separadas com ponto e vírgula). Para utilizar descritores mais adequados, consulte o Thesaurus da APA, facilitando assim a futura indexação de seu trabalho.

- Abstract em Inglês, que deve ser mais do que a tradução do Resumo, ou seja, deve ser uma "integração" com ele. Para alcançar este fim, sugere-se que ambos sejam feitos simultaneamente. Psicologia: Reflexão e Crítica tem, como procedimento padrão, fazer a revisão final do Abstract, reservando-se o direito de corrigi-lo, se necessário. No entanto, recomenda que os autores solicitem a um colega bilíngüe que revise o $A b s t r a c t$, antes de submeter o manuscrito. Este é um item muito importante de seu trabalho, pois em caso de publicação será disponibilizado em todos os indexadores da revista. - Keywords (tradução das palavras-chave).

\section{Corpo do Texto}

Esta parte do manuscrito deve começar em uma nova página, numerada como página três (3). Não é necessário colocar o título do manuscrito nesta página. Cada página subsequente deve estar numerada. Não inicie uma nova página a cada subtítulo. Separe-os usando uma linha em branco. Quando o manuscrito for um relato de pesquisa, o texto deverá apresentar, as páginas de Rosto e Resumos, Introdução, Método, Resultados, Discussão e Referências. Estes subtítulos devem aparecer centrados no texto, antecedidos e seguidos por uma linha em branco. Se necessário, outros subtítulos, tais como Conclusões ou Considerações Finais, podem ser acrescentados. Em alguns casos, pode ser conveniente apresentar Resultados e Discussão juntos, embora esta estratégia não seja recomendável como regra geral. Notas de rodapé devem ser evitadas sempre que possível. No entanto, se não houver outra possibilidade, devem ser indicadas por algarismos arábicos no texto e listadas, após as referências, em página separada, intitulada Notas. A inclusão de Figuras e Tabelas devem ser indicadas no texto e apresentadas em Anexo. As palavras Figuras e Tabelas que aparecerem no texto devem, sempre, serem escritas com a primeira letra em maiúscula e devem vir acompanhadas do número respectivo ao qual se referem. A utilização de expressões "a Tabela acima" ou "a Figura abaixo", não devem ser utilizadas, porque no processo de editoração a localização das mesmas pode ser alterada. As normas 
não incluem a denominação Quadros ou Gráficos, apenas Tabelas e Figuras. Os manuscritos nas demais categoria editoriais deverão apresentar títulos e subtítulos de acordo com o caso.

Observe, com muita atenção, as normas de citação. Dê, sempre, crédito aos autores e às datas de publicação de todos os estudos referidos. Todos os nomes de autores cujos trabalhos forem citados devem ser seguidos da data de publicação, na primeira vez que forem citados em cada parágrafo. A citação literal de um texto exige a referência ao número da página do trabalho do qual foi copiada e deve ser apresentada entre aspas, com recuo da margem esquerda, quando citações longas. Todas as citações secundárias devem informar a referência original Evite, no entanto, sempre que possível, utilizar citações secundárias, especialmente quando o original pode ser recuperado com facilidade. Todavia, caso seja imprescindível, informe: sobrenome do autor, a data, o nome do autor que faz a citação original e a data de publicação do estudo. ATENÇÃO: Não use os termos apud, op. cit, id. ibidem, e outros. Eles não fazem parte das Normas da APA.

Psicologia: Reflexão e Crítica recomenda que os autores revisem seu texto, observando ligação entre as seções e subtítulos utilizados. Parágrafos de frase única devem ser evitados pois fragmentam o texto. Salienta que os objetivos do estudo devem ser claramente explicitados no início do texto, remetendo à revisão da literatura existente na área e aos procedimentos metodológicos. Todos os estudos citados no texto devem ser listados na seção de referências. Apenas as obras consultadas e mencionadas no texto devem aparecer naquela seção.

\section{Lista de Referências}

Inicie uma nova página para a seção de Referências. Utilize espaço duplo nesta seção e não deixe um espaço extra entre citações. As referências devem ser citadas em ordem alfabética, pelo sobrenome dos autores. Em casos de referências a múltiplos estudos do mesmo autor, utilize ordem cronológica, ou seja, do estudo mais antigo ao mais recente deste autor, para listá-los nesta seção. A coincidir autores e datas, utilizar a primeira letra do título para listar em ordem alfabética, as referências. Nomes de autores não devem ser substituídos por travessões ou traços. Cada uma das Referências deve aparecer como um novo parágrafo, deixando cinco espaços da margem esquerda na primeira linha (use o tabulador). Revise as normas da revista, cuidadosamente, antes de preparar suas referências, para obedecer a todos os critérios. Não use comandos como negrito ou itálicos nesta seção. Os grifos devem ser sublinhados.

\section{Anexos}

Os anexos devem ser apresentados em uma nova página, após as referências. As páginas devem ser numeradas consecutivamente, em espaço duplo. Os anexos devem ser indicados no texto e apresentados no final do manuscrito, identificados pelas letras do alfabeto maiúsculas (A, B, C, e assim por diante) e intitulados adequadamente. Somente utilize anexos se isso for realmente imprescindível para a compreensão do texto. Ao invés de incluir instrumentos ou outros materiais, os autores podem optar por informar aos leitores, através de uma Nota, sobre a disponibilidade dos mesmos e os procedimentos para serem obtidos.

\section{Figuras e Tabelas}

Devem ser apresentadas com as respectivas legendas e títulos, uma em cada página. As Figuras e Tabelas devem ser apresentadas em Preto e Branco e não devem exceder 17,5 de largura por 23,5 cm de comprimento. Devem ser, preferencialmente, elaboradas no MSWord. Não produza Figuras gráficas com cores ou padrões rebuscados que possam ser confundidos entre si, quando da editoração da revista. Os títulos das Tabelas devem ser colocadas no alto das mesmas e devem indicar o conteúdo das mesmas, em até 15 palavras. A primeira letra de cada palavra do título das Tabelas deve ser escrita em letra maiúscula, sendo que as demais letras devem ser minúsculas. Não utilize letras maiúsculas, negritos ou itálicos dentro da Tabela. Procure não utilizar abreviações nas Tabelas, mas se imprescindível indique-as claramente no texto. Os títulos das Figuras devem ser apresentados abaixo das mesmas, sempre em letra minúscula. Lembre que as normas não incluem a denominação Quadros ou Gráficos, apenas Tabelas e Figuras.

\section{Notas sobre os Autores}

Incluir uma breve descrição sobre as atividades atuais dos autores e sobre a sua formação.

\section{Exemplos de Citações no Corpo do Texto}

Os exemplos abaixo auxiliam na organização de seu manuscrito, mas, certamente, não esgotam as possibilidades de citação em seu trabalho. Utilize o Publication Manual of the American Psychological Association (1994, $4^{a}$ edição) para verificar as normas exigidas para fazer referência a outros veículos de divulgação que não constam na lista abaixo. 
Textos com Autoria Múltipla

- dois autores: cite os dois nomes sempre que o artigo for referido no texto, acompanhado da data do estudo entre parênteses.

- três a cinco autores: cite todos os autores na primeira referência, seguidos da data do estudo entre parênteses. A partir da segunda referência, utilize o sobrenome do primeiro autor seguido de "e colaboradores" e da data, caso seja a primeira citação no parágrafo.

- seis ou mais autores: cite apenas o sobrenome do primeiro autor, seguido de "e colaboradores" e da data. Porém, na seção de Referências todos os nomes dos autores deverão ser relacionados.

\section{Citação de Obras Antigas e Reeditadas}

Utilize o seguinte formato:

Autor (data de publicação original/data de publicação consultada).

\section{Citação Secundária}

Trata-se da citação de um artigo discutido em outra publicação consultada, sem que o original tenha sido utilizado. Por exemplo: "Piaget (1932, citado por Flavell, 1996)

...”. Na seção de referências citar apenas a obra consultada (no caso, Flavell, 1996).

Exemplos de Citação na Lista de Referências Artigo de Revista Científica

Jou, G. I. de \& Sperb, T. M. (1999). Teoria da mente: Diferentes abordagens. Psicologia Reflexão e Crítica, 12, 287-306.

Artigo de Revista Científica paginada por Fascículo Proceder de acordo com o indicado acima, e incluir o número do fascículo, entre parênteses, sem sublinhar, imediatamente após o número do volume.

\section{Artigo de Revista Científica no Prelo}

Indicar no lugar da data, que o artigo está no prelo. Incluir o nome do periódico, sublinhado, após o título do artigo. Não referir data e números do volume, fascículo ou páginas até que o artigo seja publicado. No texto, citar o artigo indicando, entre parênteses, que está no prelo.

\section{Texto publicado em Revista de Divulgação} Comercial

Use o exemplo abaixo para textos com autor indicado. Caso o texto não indique o autor, iniciar com o título, informar ano, dia e mês, nome da revista, volume e páginas. Por exemplo:

Secco, A. (1999, 10 de Março). Os novos colegas. Veja, 32, 122-123.

\section{Livro com Autoria Única}

Biaggio, A. M. B. (1975). Psicologia do desenvolvimento. Petrópolis, RJ: Vozes.

\section{Livro Organizado por um Editor}

Carvalho, A. M. (Org.). (1999). O mundo social da criança: Natureza e cultura em ação. São Paulo, SP: Casa do Psicólogo.

\section{Capítulo de Livro}

Spinillo, A. G. (1996). O uso de coesivos por crianças com diferentes níveis de domínio de um esquema narrativo. Em M. G. B. B. Dias \& A. G. Spinillo (Orgs.), Tópicos em psicologia cognitiva (pp. 84-119). Recife: Editora da UFPE.

Capítulo ou Artigo Traduzido par o Português de uma Série de Múltiplos Volumes

Freud, S. (1969). Análise terminável e interminável (M.A.M. Rego, Trad.). Em J. Salomão (Org.), Edição standard brasileira de obras completas de Sigmund Freud (Vol. 23, pp. 225-270). Rio de Janeiro: Imago. (Original publicado em 1937)

\section{Livro Traduzido para o Português}

Bardin, L. (1979). Análise de conteúdo ( L. A. Reto \& A. Pinheiro, Trad.). São Paulo: Edições 70/Livraria Martins Fontes. (Original publicado em 1977)

\section{Texto Publicado em Enciclopédia}

Stroll, A. (1990). Epistemology. Em The new encyclopedia Britannica (Vol.18, pp. 466-488). Chicago: Encyclopedia Britannica.

Trabalho apresentado em Congresso, mas nãopublicado

Haidt, J., Dias, M. G. \& Koller, S. (1991, Fevereiro). Disgust, disrespect and culture: Moral judgment of victimless violation in the USA and Brazil. Trabalho apresentado no Annual Meeting of the Society for CrossCultural Research, Isla Verde, Puerto Rico.

\section{Trabalho apresentado em Congresso com Resumo} publicado em Anais

Piccinini, C. (1998). A interação mãe-bebê: Algumas perspectivas para a observação de comportamentos da díade [Resumos]. Em Associação Nacional de Pesquisa 
e Pós-Graduação em Psicologia (Org.), Anais, VII Simpósio de Pesquisa e Intercâmbio Científico (p. 26). Gramado, RS: ANPEPP.

\section{Teses ou Dissertações Não-Publicadas}

Cecconello, A. M. (1999). Competência social, empatia e representação mental da relação de apego em famílias em situação de risco. Dissertação de Mestrado não-publicada, Curso de Pós-Graduação em Psicologia do Desenvolvimento, Universidade Federal do Rio Grande do Sul. Porto Alegre, RS.

\section{Obra Antiga e Reeditada em Data Posterior}

Bronfenbrenner, U. (1996). A ecologia do desenvolvimento humano: Experimentos naturais e planejados. Porto Alegre: Artes Médicas. (Original publicado em 1979)

\section{Autoria Institucional}

American Psychological Association (1994). Publication manual ( $4^{\mathrm{a}} \mathrm{ed}$.). Washington, DC: Autor.

\section{Comunicação Pessoal}

Pode ser carta, mensagem eletrônica, conversa telefônica ou pessoal. Cite apenas no texto, dando as iniciais e o sobrenome do emissor e a data completa. Não inclua nas referências. Por exemplo: S. H. Koller (comunicação pessoal, 09/11/2000).

\section{Web Site ou Homepage}

Para citar um Web Site ou Homepage na íntegra, incluir o endereço dos mesmos no texto, de preferência entre vírgulas ou parênteses. Não é necessário listá-lo nas Referências. Por exemplo: (www.anpepp.org.br).

\section{Artigos Consultados em Indexadores Eletrônicos}

A referência a este item mudou desde a publicação da $4^{a}$ edição do Manual da APA. Siga o exemplo abaixo:

Correa, J. \& MacLean, M. (1999). Era uma vez ... um vilão chamado Matemática: Um estudo intercultural da dificuldade atribuída à Matemática. Psicologia: Reflexão e Crítica, 12, 173-194. Retirado em 02/10/2000, do SciELO (Scientific Eletronic Library Online) no World Wide Web: http://www.scielo.br/prc

Resumos Consultados em Indexadores Eletrônicos A referência a este item mudou desde a publicação da $4^{a}$ edição do Manual da APA. Siga o exemplo abaixo:

Parente, M. A. M. P., Capuano, A. \& Nespoulous (1999). Ativação de modelos mentais no recontar de histórias de idosos [Resumo]. Psicologia: Reflexão e
Crítica, 12, 157-172. Retirado em 22/07/2000, do IndexPsi Periódicos) no World Wide Web: http:// www.psicologia-online.org.br/psiindex.html

Endereço para Contato

Sílvia H. Koller, Editora

Revista Psicologia Reflexão e Crítica

CPG Psicologia do Desenvolvimento

Universidade Federal do Rio Grande do Sul

Rua Ramiro Barcelos, 2600 - 90035.003, Porto Alegre, RS.

Fones: (51) 3309507/3165150

Fax: (51) 3304797

E-mail: revista@psico.ufrgs.br

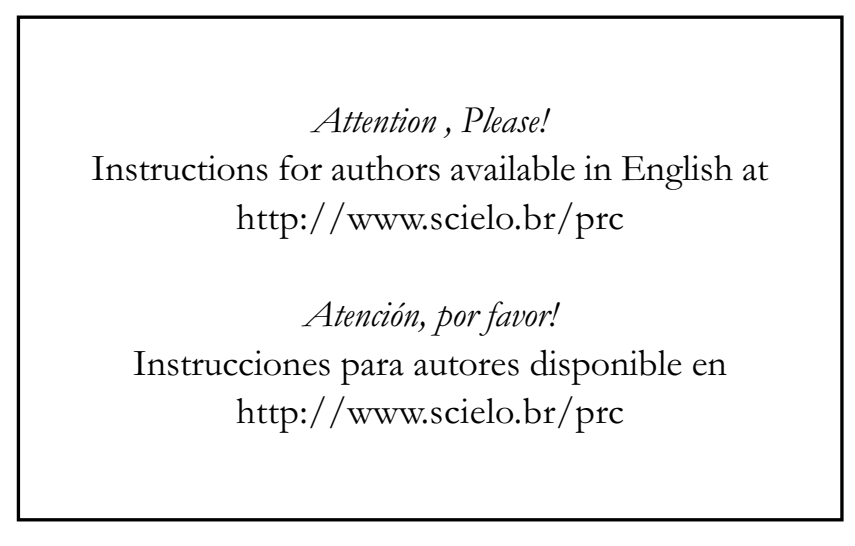

Psicologia: Reflexão e Crítica, 2000, 13(3), pp.v-xi 


\section{Antes de Enviar seu Manuscrito}

- Faça uma revisão cuidadosa do texto com relação ao Português e à digitação

- Solicite a um colega bilíngüe que revise o Abstract

- Revise, cuidadosamente, o texto, no que diz respeito às normas de publicação da revista

- Solicite a um colega de área que faça uma apreciação prévia de seu manuscrito, para garantir a qualidade e tornar o processo editorial mais ágil

Verifique, então, os seguintes itens:

\section{Primeira Submissão}

O envelope endereçado à revista contem:

( ) carta de encaminhamento

( ) assinada por todos os autores,

( ) autorização para o início do processo editorial;

( ) concessão dos direitos autorais para a revista; e,

( ) compromisso de respeito a todos os aspectos éticos inerentes a realização de um trabalho científico.

( ) uma cópia em disquete (MSWord ou WordPerfect para PC)

( ) quatro cópias do Manuscrito, seguindo as normas de publicação, revisados CUIDADOSAMENTE ( ) texto - espaço duplo
( ) folha de rosto identificada
( ) folha de rosto sem
identificação
( ) resumo
( ) palavras-chave
( ) abstract revisado
por pessoa bilingüe
( ) keywords

( ) referências em espaço duplo

( ) notas e anexos (se inevitáveis)

( ) Figuras

( ) Tabelas

\section{Manuscrito Reformulado}

( ) carta de encaminhamento especificando alterações feitas e justificando aquelas não efetuadas

( ) duas cópias do Manuscrito

( ) uma cópia em disquete (MSWord ou WordPerfect para PC).

\section{Manuscrito Aceito}

( ) carta de concessão de direitos autorais assinada por todos os autores (caso não enviada anteriormente)

( ) duas cópias da versão final do manuscrito

( ) disquete com
( ) texto em um arquivo (MSWord ou WordPerfect para PC)
( ) cada Tabela e Figura em um arquivo separado.

Endereço para Encaminhamento de Correspondência

Sílvia H. Koller, Editora / Revista Psicologia Reflexão e Crítica

CPG Psicologia do Desenvolvimento/ UFRGS

Rua Ramiro Barcelos, 2600 - 90035.003, Porto Alegre, RS. 
PSICOLOGIA: REFLEXÃO \& CRÍTICA CPG em Psicologia do Desenvolvimento da UFRGS

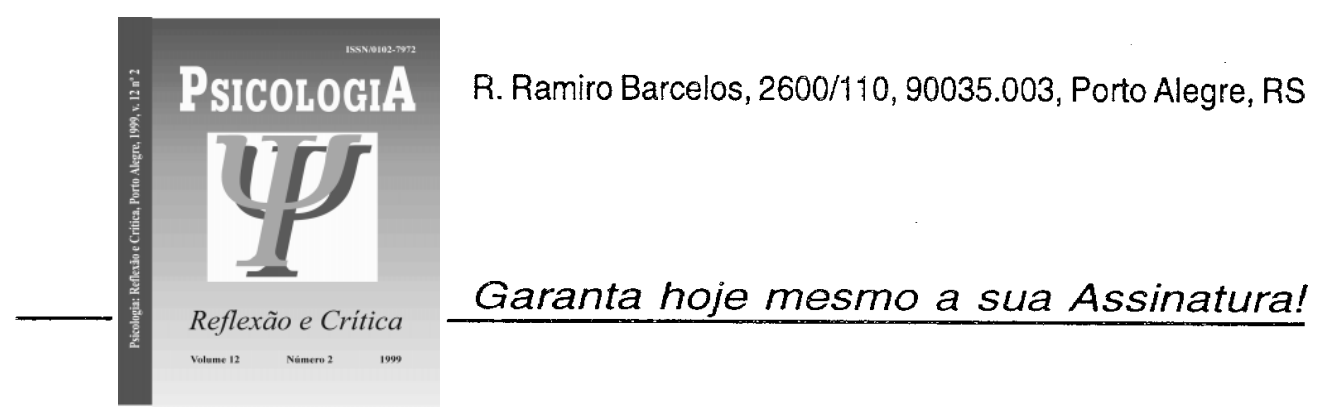

Retorne o formulário abaixo com seu endereço completo e um cheque nominal para a FAURGS (Fundação de Apoio a Universidade Federal do

Rio Grande do Sul) ou p/ comprovante de depósito bancário na Conta FAURGS - Banco do Brasil - código 972-5, Agência 1899-6, Conta 300.000-1.

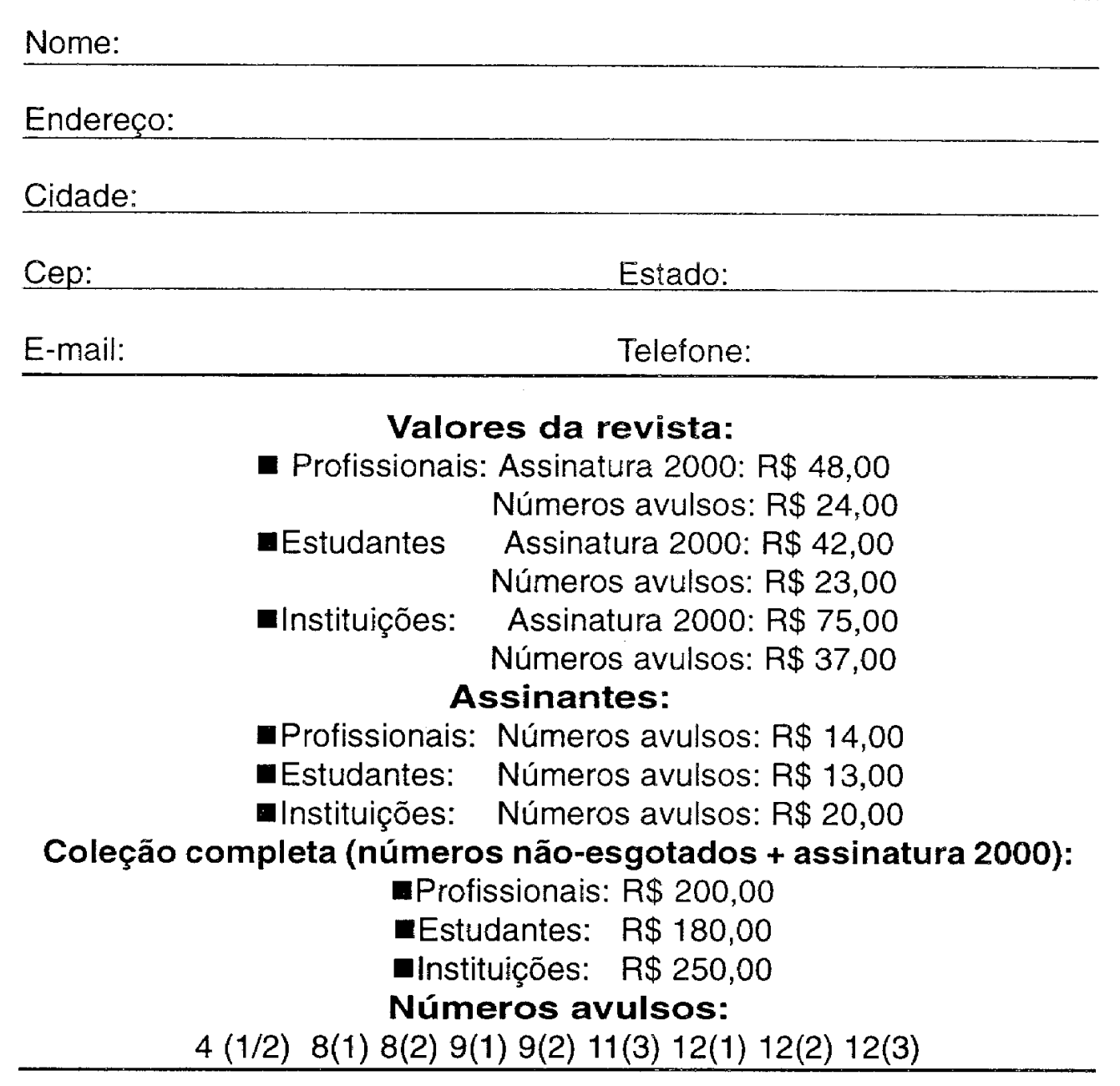

